\title{
Perception of Millennial Workforce upon ICT and Organizational Learning and Innovative Performance: The Mediating Role of Ambidexterity
}

\author{
Kosasih Kosasih and Arif Widodo Nugroho
}

\section{ABSTRACT}

\begin{abstract}
The company's future performance cannot be reflected only in the current financial performance in the financial statements. Long-term company performance can be reflected by the technology being developed. The role of information and communication technology (ICT) is very important for a company to survive and be able to compete in modern business competition in the era of industry 4.0. Meanwhile, learning organization is fostering communication, knowledge exchange in order to promote the innovation. Ambidexterity capability of organization develops structures to manage innovation and achieve sustained success over time. The purpose of this study is to examine the influence of ICT and organizational learning on firm's innovative performance which mediated by ambidexterity based on millennial workforce perception. The result of this research found that ICT has significantly positive influence on ambidexterity, but not significantly positive influence on innovative performance. Learning organization has significantly positive influence both on ambidexterity and innovative performance. Ambidexterity has significantly influence on innovative performance. The mediating role of ambidexterity had significantly positive enhanced the influence ICT on innovative performance. Meanwhile, ambidexterity had not significantly positive enhance the influence learning organization on innovative performance.
\end{abstract}

Keywords: Information and communication technology, Organizational learning, Ambidexterity, Innovative performance.
Submitted : March 21, 2021

Published : April 12, 2021

ISSN: $2507-1076$

DOI: $10.24018 /$ ejbmr.2021.6.2.823

Kosasih Kosasih *

Universitas Mercu Buana, Indonesia.

(e-mail: k.kosasih@ ${ }^{@}$ ercubuana.ac.id)

Arif Widodo Nugroho

Universitas Muhamadiyah Prof. Dr. Hamka, Indonesia.

(e-mail: arifwidodo.nugroho@uhamka.ac.id)

*Corresponding Author

\section{INTRODUCTION}

According to Chao, Gonzále, \& Sellens [1] the massive use of ICT is essential for economics. Jorgenson \& $\mathrm{Vu}$ [2] mentioned that it can increase economic growth and enhancing productivity [3]. ICT also produce complement innovations that enhance total factor productivity [4], [5]. Gërguri-Rashiti, Ramadani, Abazi-Alili, Dana, \& Ratten, [6] had found that the rapid technological development and the growing use of ICT in business organizations performance have become the center of attention in past few years. Many research insisted on the need of renewal and adjustment the ICT function in business organizations [7]. Currently, ICT plays the important role through increasing the knowledge base in improving management and company performance [8]. Companies which use ICT in managing internal distribution networks have a competitive advantage and improve company efficiency and performance.

Maslach [9] concluded that innovation has relationship with development of knowledge, due to it provide input to the innovation process. The failure market innovation can provide important lessons on how to make a better marketing strategy in the future. Experiencing failure were related with product innovation result [10]. Various learning processes can be gained from internal and external of organization [11] and [12]. Many firms adopt innovation capability as organization's core competence of a firm and spend billions into the $\mathrm{R} \& \mathrm{D}$ process. Yet, such implementation and investment were no guarantee for success [13]. The level of complexity of innovation can be divided into two separate dimensions, namely: the intensity of the interaction between the parts of knowledge and the number of parts of knowledge involved [14], [15]. The performance of companies that do not carry out the function of innovation will be poor or may face bankruptcy [16], [17]. The number of components of knowledge has a direct relationship with the problems faced in innovation [18] and is also influenced by tacit knowledge in solving problems [19]. Due to confidentiality, companies might hide knowledge based on experience in solving problems [20], [15].

One of the innovation problems is its relation to the knowledge component related to solution development [15]. The failure of innovation projects and innovation collaboration is influenced by innovation partnerships as a consequence of previous innovation failures so that the problems that determine the failure of these innovations can be identified. Some of the problems in innovation include: lack of resources and weak competence [21]. Companies must make radical changes in new innovations to prevent the continuation of innovation failures in the future [9]. 
Based on above explanation, ICT and organization learning are important factors in determining the success of firm's performance. The purposes of this research are to examine the effect of ICT, organization learning and ambidexterity on firm's innovative performance. The data gained by distributing questionnaires to 152 millennial employees who working in 32 difference companies located in area of Jakarta, Indonesia. The purpose of this research is to examine:

1. The influence of ICT (X1) on ambidexterity (Y);

2. The influence of ICT (X1) on innovative performance $(\mathrm{Z})$;

3. The influence of organization learning (X2) on ambidexterity (Y);

4. The influence of organization learning (X2) on innovative performance $(\mathrm{Z})$;

5. The influence of ambidextrous organization (Y) on innovative performace $(\mathrm{Z})$;

6. The influence of ICT (X1) on innovative performance which mediated by ambidexterity;

7. The influence of organization learning on innovative performance mediated by ambidexterity.

\section{LITERATURE REVIEW}

\section{A. Innovative Performance}

Innovation activities is a critical importance for the competitiveness and growth of firms. It is also can be a very good way to enhance competitiveness, diversify activities and move towards more high value added activities (OECD 2007, 2010a and 2010b; [22]). Previously, corporate performance is reflected from financial perspective, customer satisfaction, learning and growth and business process [23]. The future performance of company cannot be reflected from current financial performance in financial report. Long-term company performance can be provided by technologies being developed. According to Lungeanu, Stern, \& Zajac [24], company that fail to achieve their innovation goals will modify their portfolio of technology-sourcing vehicles. The type of change chosen depends on the financial resources they have. The ability of the company's financial resources will affect the company's innovative performance. The literature in defining of innovation, measurement and the identification of variables that influence the level of innovation activities is vary way [6]. Ajayi [25] classified innovative changes into firms' output, the mechanism, which is directly involved, process innovation and mechanism which is indirectly involved. Product innovation performance has two key dimensions: efficiency and efficacy. Efficiency reflects the mechanisms or efforts that the firm uses to innovate, and efficacy reflects the final results of innovation [16]. Therefore, efficiency helps to achieve efficacy [26]. Preda, Crisan, \& Stanica [27] using the SII indicator to measure innovation performance, the countries analyzed in the scoreboard are classified, every year, into four groups/clusters, which are: innovation leaders (Sweden, Denmark, Germany and Finland), innovation followers (Luxembourg, Netherlands, Belgium, UK, Ireland, Austria, France, Slovenia, Estonia and Cyprus), moderate innovators (Italy, Czech Republic, Spain, Portugal, Greece, Hungary, Slovakia, Malta, Croatia,
Lithuania and Poland) and modest innovators (Romania, Latvia and Bulgaria).

Tajasom, Hung, Nikbin, \& Hyun [28] measured innovation performance by the speed level of new products introduction to the market, new product's percentage of all product, the number of new product and service projects, a new work processes and methods, the quality of new products/series introduced, the number of intellectual property protection registered and the new administrative system and the process in line with the firm's environment. Cruz-Cázares, BayonaSáez, \& García-Marco [29] measured innovation efficiency relation to firm performance by using input $(R \& D$ capital stock and high skill staff) and output (number of product innovations and the number of patents). Abbas \& Raja [30] measured innovative performance by idea generation, idea promotion, and idea realization. Kilic, Ulusoy, \& Gunday [31] measured innovative performance measures by employed to expose the effects of realized innovations on firm performance, namely, financial, production, and market performances. Higón [32] classified determinants of innovation as: characteristics of the firm, management factors and firm's environment variables.

\section{B. Information and Communication Technology (ICT)}

Bloom, Garicano, Sadun, \& Van Reenen [33] argued that some studies found that ICT has an effect on firm organization. These technologies have two components: information technology (IT) and communications technology (CT). IT has spread of cheap storage and processing of data and make cheaper information. CT has spread of cheap wired and wireless communications to easier communication each other. Currently almost all organizations use ICT to support their business processes [34]. According to Chao et al. [1] the widespread of ICT is important for economic activities by direct increasing of productivity and economic growth. ICT could improve productivity if employee had educational, training, and technical skill. ICT enhance efficiency technologies and create competitive advantage through innovation. The use of ICT represents a fundamental source of competitiveness and growth for firms and countries by exploiting them [32]. ICT have dramatically reduced costs of communication and information processing, which can lead to new enhanced business processes and work practices, which lead to big productivity increases; this is achieved initially by reducing costs and increasing output quality, and subsequently by designing new products/services and improving important intangible aspects of existing products/services, such as convenience, timeliness, quality, personalization [35].

Garcia-Alcaraz, Maldonado-Macias, Alor-Hernandez, \& Sanchez-Ramirez [36] measured ICT by effective of B2B commerce, internet used for business management, product customization, coordination and integration. Preda et al. [27] measure ICT from The Global Information Technology Report (GITR) which mentioned a set of dimensions of ICT, namely: the environment of ICT, the using ICT readiness, the ICT usage level, and the effect of ICT.

\section{Organizational Learning $(O L)$}

According to Guinot, Chiva, \& Mallén [37] the definition of organizational learning is a characteristic of organizational and management which facilitate organizational learning or 
allowing an organization to learn [37]. Organizational learning, or the process by which organizations learn [37], can be defined as the process through which organizations change or modify their mental models, processes, or knowledge, maintaining or improving their performance [38]-[43]. According to Chiva, Alegre, and Lapiedra [44] and Chiva and Alegre [45] experimentation, risk taking, interaction with the external environment, dialog, and participation are the factors that facilitate the process of organizational learning.

Erkelens, van den Hooff, Huysman, \& Vlaar [46] identify three processes that are part of knowledge pollination from locally embedded knowledge in organization learning, which are: organized learning, learning in practice and network learning. Yan, Yu, \& Dong [47] classified organizational learning into two dimensions, namely: strategic and business learning. Organization learning consist of knowledge acquisition, distribution and interpretation of information and organizational memory. According to Guinot et al. [37] organizational learning has five dimensions, which are: experimentation, risk taking, interaction with the external environment, dialog, and participation.

\section{Ambidexterity}

Junni, Sarala, Taras, \& Tarba [48] found that ambidexterity has important role in maintenance sustained competitive advantage of organizations. Ambidexterity of organization has been widely discussed for more than twenty years in management literature and it has not been explored thoroughly and it still interesting topic for research [49]. According to Nosella, Cantarello, \& Filippini [50] recently ambidexterity has increased significantly. Goh \& Richards [51] described ambidexterity as a set of actions that ensures learning capability: effective generation of ideas by implementing a set of practices such as experimentation, problem solving, working in team and decision making. Ambidexterity is derived from the Latin ambos mean 'both', and dexter means 'right'. Thus, ambidexterity defined as 'right on both sides'. Duncan \& Duncan [52] are the first researcher to use the term of 'ambidexterity'. Their concept has been used to describe a variety of distinctions in organization behaviour and outcomes. Gibson [53] noted that ambidexterity is the organization's ability to do two different things at the same time, such exploitation and exploration, efficiency and flexibility, or alignment and adaptability. Lis et al. [49] mentioned that organizational ambidexterity is listed among up-to-date concepts recommended for managers to cope with turbulence and multidimensionality of the business environment.

Cembrero [54] argued that companies have decided to create an innovation unit or embed innovation into all the functions. The decision reflects the balance of the maximum exploitation of their existing base of skills, products, and services with the maximum exploitation of them to ensure their survival in the long term. Radical innovation is the critical point which leads to the concept of "ambidextrous organization" which reflect the ability to explore and exploit. Turner, Maylor, \& Swart [55] defined ambidexterity as the ability to use and improve existing knowledge (exploitation) and the also ability to create new knowledge (exploration) necessary. They proposed that the generic meaning of ambidexterity is the ability to achieve two apparently contradictory objectives simultaneously. Ambidexterity is defined as the ability to simultaneously explore and exploit their internal and external resources to meet today's business needs [56] and to enhance to gain competitive advantage in new areas by leveraging existing assets and capabilities from the mature side of the business. [57]. Organizational ambidexterity reflects a firms' ability to both explore new competences and exploit existing competences has attracted considerable interest [58].

Cao, Gedajlovic, \& Zhang [59] measured ambidexterity into two dimensions, namely: the balanced dimension of ambidexterity (BD) and the combined dimension into ambidexterity (CD). Dimensions of BD emphasizes relative magnitude of exploitation and exploration because excessive devotion to either side will cause performance risks. The dimensions of $\mathrm{CD}$ ambidextrous organizational culture by $\mathrm{Z}$. Wang et al. [58] are: organizational diversity (OD) \& shared vision (SV). Junni et al. [48] measured ambidexterity dimensions by exploration and exploitation. Three items were used to measure exploration by $\mathrm{Fu}$ et al. [56] are creating, experimenting and love to play with new ideas in order to develop new services. Two items were used to measure exploitation are conducting activities using existing knowledge and conduct those activities which clearly fit with existing firm policy.

\section{RESEARCH METHODOLOGY AND FRAMEWORK}

This research used a quantitative approach trough questionnaire survey method. The participant of research is 152 millennial employees in Indonesia spread across four provinces (Jakarta, Banten, West Java and, Riau) determined by purposive sampling based on participant willingness to fill in the questionnaire at the time of the research was conducted. The respondents are working for 32 foreign investment companies from 12 countries. The survey was carried out within Indonesia. This study tested the correlation between variables (dependent and independent) to examine the effect between the variables tested. The data was collected by a questionnaire in the form of a Likert scale model with five scale 1-5 which indicates answers: strongly disagree, disagree, neutral, agree, and strongly agree. The questionnaire was made by researchers based on the theoretical dimensions or indicators from the experts.

The hypotheses examination was tested by AMOS application. The validity and reliability construct are tested by analysis at convergent validity and discriminant validity of the indicators. Test of discriminant validity by comparing the square root of average variance extracted (SR of AVE) with cross loading from each indicator. If the AVE construct is greater than the cross-loading factor, it can be concluded to have good discriminant validity. In this research, loading factor is 0,5 value. If a loading factor value $<0.50$, it must be eliminated in order to obtain a specific model.

\section{A. ICT and Ambidexterity}

Del Giudice, Soto-Acosta, Carayannis, \& Scuotto [60] found that information technology capability, knowledge management capability and environmental dynamism are positively associated with innovation ambidexterity. Some 
researchers found that using the proper IT solutions may enhance the speed of knowledge exploration and exploitation [61], [62]. Im, Rai, \& Im [63] found that for customers, the use of ICT by operations supports systems (OSS) and interpretation support systems (ISS) enhances contextual ambidexterity. The effect level of both OSS and ISS use on contextual ambidexterity influenced by the duration of the relationship. IT and interdependent decision making, are key coordination mechanisms promoting contextual ambidexterity. Bresciani, Ferraris, \& Del Giudice [64] found evidence that to obtain higher ambidexterity MNEs must develop knowledge management (KM) and ICT capabilities. KM capabilities indirectly enhance ambidexterity through firms ICT capabilities. Based on the above studies, our research proposes the following hypothesis:

H1: ICT has a positive influence on ambidextrous organization

\section{B. ICT and Innovative Performance}

The concrete outcome of productivity improvement was achieved by ICT to enable resource optimization [65]. ICT's has an effect on firm productivity [66], business performance and innovation processes [67]. ICT provides a strong innovation drive even in such innovation averse national contexts, in which the traditional innovation determinants do not drive innovation of processes, products or services [68]. ICT also induced innovation potential [69]. Preda et al. [27] on their study showed that for the EU-28 countries, there is a relationship between the innovation performance (measured by SII) and the ICT readiness (measured by NRI), which can be modeled by a unifactorial linear regression. This relationship proved to be valid for a long period of time (2006-2013). The impact of ICT on organization depends on the type of ICT application and innovation activities in various resources and incentives required for implementation [32]. Based on the above studies, our research proposes the following hypothesis:

H2: ICT has a positive influence on innovative performance

\section{Organizational Learning Capability and Ambidexterity}

March [70] suggested to associate exploration and exploitation with two types of leaning activities-business learning and strategic learning. Amaral et al. [71] argued that ambidexterity may indeed be viewed as a strategic objective, representing the desired ends to be achieved via the appropriate organizational learning. The study of Park, Song, Yoon, \& Kim [72] results indicated that individual innovative behavior is influenced by the organizational learning culture through work engagement. Yan et al. [47] found that exploration and exploitation are different but they are both related with organizational ambidexterity. Bresciani et al. [64] found evidence that MNEs need to develop knowledge management capabilities to produce greater ambidexterity performance. Based on the above studies, our research proposes the following hypothesis:

H3: Organization Learning Capability has a positive influence on ambidextrous organization

\section{Organizational Learning Capability and Innovative Performance}

Learning organization culture was found to be a significant predictor of many Korean firms' innovative culture, product, and service (technical) innovations, and process (administrative) innovations [73]. Organizations must consider various components of the learning organization to develop innovative capacity [72]. The research of Curado et al. [26] results showed that the antecedents of knowledge sharing positively affect an organization's learning capacity that in turn positively affects innovation performance. Siagian \& Ikatrinasari [74] found that knowledge management in learning organization has a positive significantly effect on process and product innovation. Valaei, Rezaei, \& Ismail [75] argued that exploitative and explorative learning strategy, are several causal conditions of innovation outcome in SMEs organization. The primary aim of organizational learning is to enhance performance quality and quantity and lead organizations to superior long-term performance [76]. Organizational learning influences organizational performance positively, both directly and indirectly through organizational innovation [76]. The research findings of Jiménez-Jiménez \& Sanz-Valle [77] showed that both variables of organizational learning and innovation has contribute positively to firms' innovation. Based on the above studies, our research proposes the following hypothesis:

H4. Organization Learning Capability has a positive influence on the innovative performance

\section{E. Ambidexterity and Innovative Performance}

Relationships et al. [63] found that contextual ambidexterity enhance exploitative and exploratory knowledge sharing, thus it is promoting sustained performance benefits for both partners. Ambidextrous approach encompassing both exploration and exploitation activities has yielded mixed results on the performance implications of organisational ambidexterity [78]. Fu et al. [56] found the effect of ambidexterity on performance is significant if the firm have higher levels of organizational capital. Research of C. L. Wang \& Rafiq [79] has found that organizational ambidexterity have an important role in improving firm performance. They also found significant relationships between culture and contextual ambidexterity and innovation outcomes. Junni et al. [48] argued that the ambidexterity are thought to benefit the organizational performance [48]. O'Reilly \& Tushman [57] found linking ambidexterity to performance are robust. In aggregate, his literature studies suggest that ambidexterity is positively associated with firm performance [80]. Environmental complexity positively moderates the relationship between Organizational Ambidexterity and organizational performance, such that when complexity is high, this influence will be stronger. Ambidextrous firm strategy has a positive effect on four dimensions of performance: sales revenues, profits, customer satisfaction, and new product introductions [81]. Junni et al. [48] found that organizational ambidexterity was positively and significantly associated with performance. Popadić, Černe, \& Černe [82] and Kosasih, Wibowo, \& Saparuddin [83] found that ambidexterity of exploratory and exploitative innovation positively influence on firms' innovation performance. The 
study from Bresciani et al. [64] and Faisal Ahammad, Mook Lee, Malul, \& Shoham [84] argued that many studies found a positive relationship between organizational ambidexterity and several organizational outcomes. Based on the above studies, our research proposes the following hypothesis:

H5. Ambidextrous Organization has a positive influence on the innovative performance

Bresciani et al. [64] also found the relationship between ICT, Knowledge management and Ambidexterity in a new context of analysis. The ICT is measured by internal use, collaboration \& communication. The knowledge management is measured by knowledge creation \& integration. The ambidexterity of alliance measured by project lengths, team size, project stage \& alliance organization count.

\section{F. Theoretical Framework}

Based on theoretical and previous research described above, the theoretical frameworks in this research can be constructed by the hypotheses below:

1. Hypothesis 1: ICT has a significance influence on ambidexterity;

2. Hypothesis 2: ICT has a significance influence on the innovative performance;

3. Hypothesis 3: Organization learning capability has a significance influence on the ambidexterity;

4. Hypothesis 4: Organization learning capability has a significance influence on innovative performance;

5. Hypothesis 5: Ambidexterity has a significance influence on the innovative performance.

6. Hypothesis 6: ICT has a significance influence on innovative performance mediated by ambidexterity;

7. Hypothesis 7: Organization learning capability has a significance influence on innovative performance mediated by ambidexterity.

The constellation model based on the theoretical framework can be described in the model constellation as follows:

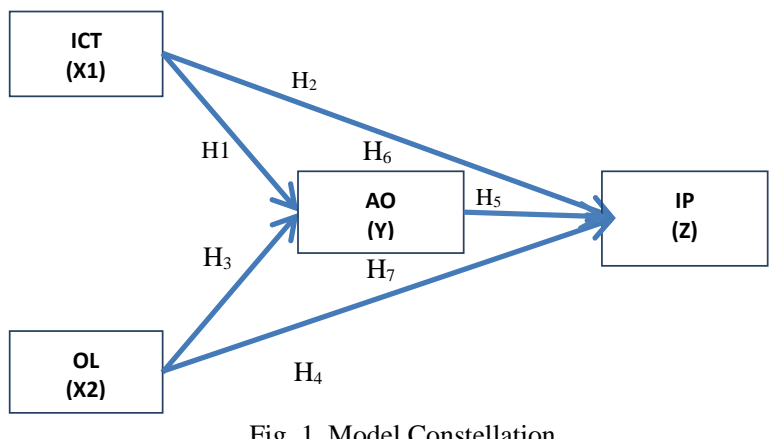

Fig. 1. Model Constellation.

\section{RESULTS AND DISCUSSION}

\section{A. CFA Validity \& Reliability Test}

The validity and reliability of model construct are tested by confirmatory factor analysis (CFA). The validity of model construct is evaluated by comparing the p-value at the estimated output with an alpha of $5 \%$. If the p-value is less than $5 \%$, then the indicator model construct is concluded valid. The reliability of model construct is evaluated by comparing the value of $\mathrm{CR}$ and $\mathrm{VE}$ with the minimum value of CR7 0.7 and $A V E \geq 5$. If the value of CR7 more than 0.7 and value of AVE more than 5, then the indicator model construct is concluded reliable. Based on the instrument validity test by Pearson's correlation with cut-off correlation coefficient $(\mathrm{r}$ table) $>0.159$, it resulted that questionnaire instruments of variable IT (IT1, IT2, IT3, IT4, IT5, IT6, IT7, IT8, IT9), variable LO (LO1, LO2, LO3, LO4, LO5, LO6, LO7, LO8, LO9 \& LO10), variable AO ( AO1, AO2, AO3, AO4, AO5, AO6, AO7, AO8, AO9, AO10) and variable IP (IP1, IP2, IP3, IP4, IP5, IP6 ,IP7, IP8, IP9) have correlation coefficient $>0,159$. Therefore, we can summarize that all indicators in this research are valid. Based on the instrument reliability test by using Cronbach alpha with cut-off value of 0.7 , it resulted that all variables (IT, LO, AO and IP) have Cronbach alpha $>0,7$. Therefore, we can summarize that all indicators in this research are reliable.

\section{B. SEM Model Test}

\section{Evaluation of Structural Model}

Construct validity has been tested by calculate convergent validity and discriminant validity. Convergent validity test using loading factor $>0,7$ and discriminant validity test of each variable that must be $>$ cross loading other variables $5 \%$. Based on convergent validity test of each variable in this study shown that all item indicators are valid with the loading factor greater than 0.05 . The result of construct validity test using AVE indicator as shown in the table below:

\begin{tabular}{ccc}
\multicolumn{3}{c}{ TABLE I: CONSTRUCT VALIDITY TEST USING AVE } \\
\hline Variable & CR & VE \\
\hline Information \& Communication & 0.932 & 0.605 \\
Technology (X1) & 0.909 & 0.501 \\
Learning Organization (X2) & 0.926 & 0.561 \\
Ambidexterity (Y) & 0.859 & 0.505 \\
\hline Innovative Performance (Z) &
\end{tabular}

The following is the modified equation model (Fig. 2).

Thus, the indicator is declared valid to measure the variable.

Meanwhile, based on the cross-loading test, it resulted that the overall indicators of authentic followership, ambidextrous leadership, readiness to changes, and innovative performance indicators generate greater cross loading value compared to cross loading on other variables. Thus, it can be stated that each indicator is able to measure the latent variables that correspond to the indicator.

\section{Construct Reliability Test}

Calculations that can be used to test construct reliability are Cronbach alpha and composite reliability. The test criteria states that if the reliability composite is worth greater than 0.7 and the Cronbach alpha is greater than 0.6, the construct is concluded reliable. The calculation results of composite reliability and Cronbach alpha can be seen through the summary presented in the following table:

TABLE II: CONSTRUCT RELIABILITY TEST

\begin{tabular}{|c|c|c|}
\hline Variable & $\begin{array}{c}\text { Cronbach's } \\
\text { Alpha }\end{array}$ & Composite Reliability \\
\hline ICT & 0.665 & 0.817 \\
\hline Learning Organization & 0.865 & 0.897 \\
\hline Ambidexterity & 0.778 & 0.846 \\
\hline Innovative Performance & 0.800 & 0.863 \\
\hline
\end{tabular}




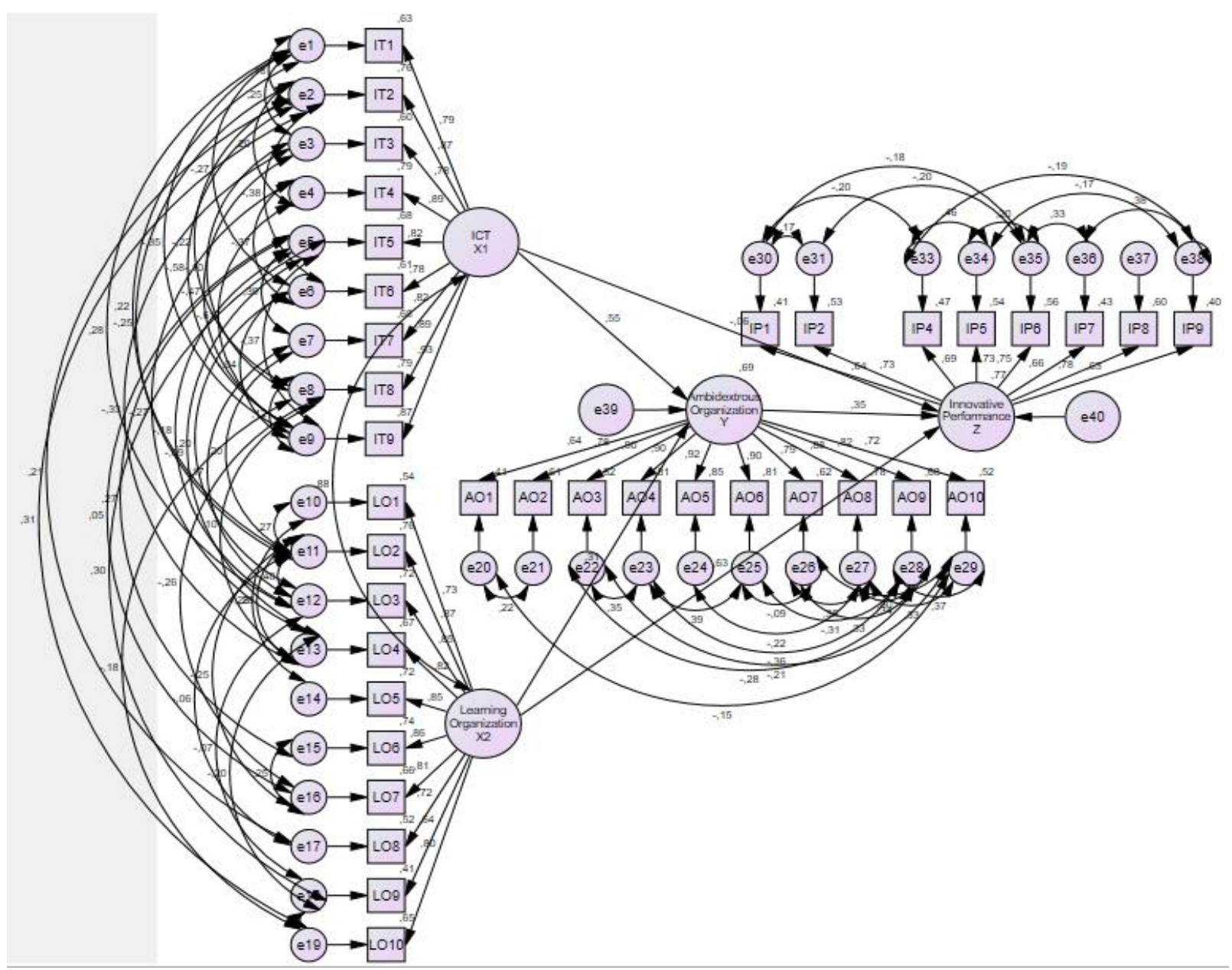

Fig. 2. Outer Loading Test.

TABEL III: GOODNESS OF FIT MODEL TEST

\begin{tabular}{|c|c|c|c|c|}
\hline Goodness of Fit & $\begin{array}{l}\text { Cut-off- } \\
\text { Value }\end{array}$ & $\begin{array}{c}\text { Before } \\
\text { modified }\end{array}$ & $\begin{array}{c}\text { After } \\
\text { modified }\end{array}$ & Description \\
\hline Significance Probability(p) & $\geq 0,05$ & 0,000 & & Bad fit \\
\hline CMIN/DF & $<2,00$ & 2,480 & 1,841 & Good fit \\
\hline GFI & $>0,9$ & 0,573 & 0,691 & Bad fit \\
\hline AGFI & $>0,9$ & 0,518 & 0,607 & Bad fit \\
\hline CFI & $>0,9$ & 0,769 & 0,884 & Marginal fit \\
\hline RMSEA & $<0,08$ & 0,123 & 0,093 & Bad fit \\
\hline NFI & $>0,9$ & 0,669 & 0,782 & Bad fit \\
\hline $\begin{array}{c}\text { TLIIADFcance Probability } \\
\text { (p) } 158158158158158158158158158158158158158158158158158158158158 \\
15815815815815815815815815815815815815815815815815815815815815 \varepsilon \\
15815815815815815815815815815815815815815815815815815815815815 \\
15815815815815815815815815815815815815815815815815815815815815 \\
158158158158158158158158158158158158158158158158158\end{array}$ & $>0,9$ & 0,754 & 0,860 & Marginal fit \\
\hline
\end{tabular}

Based on the table above it can be seen that the value of Cronbach's Alpha is greater than 0.6 and the composite reliability value is greater than 0.7 . Therefore, based on the calculation result of all indicators above, it expressed reliable in measuring the latent variables.

\section{Goodness of Fit (GOF) Test}

Goodness of fit model is used to determine the ability of endogenous variables to explain the diversity of exogenous variables, or in other words to determine the magnitude of the contribution of exogenous variables to endogenous variables. Goodness of fit Model in AMOS analysis is done using QSquare predictive relevance $(\mathrm{Q} 2)$. There are results of the Goodness of fit Model which are summarized in the Table III.

Based on the table above, it can be seen that there is an increase in the value of each criteria.
The R-square of the Readiness to Changes variable is 0.461 or $46.1 \%$. This can indicate that the diversity of the Readiness to Changes variable can be explained by Authentic Followership and Ambidextrous Leadership variables of $46.1 \%$, or in other words the contribution of Authentic Followership and Ambidextrous Leadership variables to Readiness to Changes is $46.1 \%$, while the rest is $54.9 \%$ is the contribution of other variables not addressed in this study. The R-square of the Innovative Performance variable is worth 0.461 or $46.1 \%$. This can indicate that the diversity of Innovative Performance variables can be explained by Authentic Followership, Ambidextrous Leadership, and Readiness to Changes variables by $58.8 \%$, or in other words the contribution of Authentic Followership, Ambidextrous Leadership, and Readiness to Changes variables to Innovative Performance by $58,8 \%$, while the remaining 
$42.2 \%$ is the contribution of other variables not addressed in this study. The Q-square value is 0.778 or $77.8 \%$. This can indicate that the diversity of Innovative Performance variables can be explained by Authentic Followership, Ambidextrous Leadership, and Readiness to Changes as a whole as much as $77.8 \%$, or in other words the contribution of Authentic Followership, Ambidextrous Leadership, and Readiness to Changes as a whole to Innovative Performance amounting to $77.8 \%$, while the remaining $23.2 \%$ is the contribution of other variables not discussed in this study.

\section{Hypothesis Test}

Significance testing is used to test whether there is an influence of exogenous variables on endogenous variables. The test criteria state that if the $\mathrm{T}$-statistics value:

If $\mathrm{P}<0,05$ at level $\alpha 5 \%$, then $\mathrm{H}_{0}$ rejected.

If $\mathrm{P}>0,05$ at level $\alpha 5 \%$, make $\mathrm{H}_{0}$ accepted.

Testing hypotheses for each hypothesis can be seen in the following table:

TABLE IV: HYPOTHESIS SUMMARY

\begin{tabular}{|c|c|c|c|c|c|}
\hline \multicolumn{2}{|c|}{ Hypothesis } & \multirow{2}{*}{$\begin{array}{c}\mathrm{CR} \\
3,461\end{array}$} & \multirow{2}{*}{$\begin{array}{c}\mathrm{p} \text {-value } \\
\text { *** }\end{array}$} & \multirow{2}{*}{$\begin{array}{c}\text { Result } \\
\mathrm{H} 1 \\
\text { accepted }\end{array}$} & \multirow{2}{*}{$\begin{array}{c}\text { Description } \\
\text { ICT significantly } \\
\text { positive influence on } \\
\text { ambidexterity }\end{array}$} \\
\hline $\mathrm{H}_{1}$ & $\mathrm{X} 1 \rightarrow \mathrm{Y}$ & & & & \\
\hline $\mathrm{H}_{2}$ & $X 1 \rightarrow Z$ & $-0,416$ & 0,678 & $\begin{array}{c}\mathrm{H} 2 \\
\text { rejected }\end{array}$ & $\begin{array}{l}\text { ICT not significantly } \\
\text { positive influence on } \\
\text { innovative performance }\end{array}$ \\
\hline $\mathrm{H}_{3}$ & $\mathrm{X} 2 \rightarrow \mathrm{Y}$ & 2,066 & 0,039 & $\begin{array}{c}\text { H3 } \\
\text { accepted }\end{array}$ & $\begin{array}{c}\text { Learning organization } \\
\text { significantly positive } \\
\text { influence on } \\
\text { ambidexterity }\end{array}$ \\
\hline $\mathrm{H}_{4}$ & $\mathrm{X} 2 \rightarrow \mathrm{Z}$ & 3,547 & $* * *$ & $\begin{array}{c}\mathrm{H} 4 \\
\text { accepted }\end{array}$ & $\begin{array}{c}\text { Learning organization } \\
\text { significantly positive } \\
\text { influence on innovative } \\
\text { performance }\end{array}$ \\
\hline $\mathrm{H}_{5}$ & $Y \rightarrow Z$ & 2,638 & 0,008 & $\begin{array}{c}\text { H5 } \\
\text { accepted }\end{array}$ & $\begin{array}{c}\text { Ambidexterity } \\
\text { significantly positive } \\
\text { influence on innovative } \\
\text { performance }\end{array}$ \\
\hline $\mathrm{H}_{6}$ & $\begin{array}{c}X 1-Y- \\
Z\end{array}$ & 2,272 & - & $\begin{array}{c}\text { H6 } \\
\text { accepted }\end{array}$ & $\begin{array}{l}\text { ICT significantly } \\
\text { positive influence on } \\
\text { innovative performance } \\
\text { by mediating } \\
\text { ambidexterity }\end{array}$ \\
\hline $\mathrm{H}_{7}$ & $\begin{array}{c}\mathrm{X} 2-\mathrm{Y}- \\
\mathrm{Z}\end{array}$ & 1,697 & - & $\begin{array}{c}\mathrm{H} 7 \\
\text { rejected }\end{array}$ & $\begin{array}{l}\text { Learning organization } \\
\text { not significantly } \\
\text { positive influence on } \\
\text { innovative performance } \\
\text { by mediating } \\
\text { ambidexterity }\end{array}$ \\
\hline
\end{tabular}

\section{Conversion of Path Diagrams into Structural Models}

The path diagram conversion in the model is intended to determine the effect directly. The direct model effects as presented in the following models:

$$
\begin{gathered}
\mathrm{AO}=0.548 \mathrm{ICT}+0.305 \mathrm{LO}, \text { Errorvar }=0.314 \\
\mathrm{R} \text {-square }=0.686
\end{gathered}
$$

$$
\begin{gathered}
\mathrm{IP}=0.062 \mathrm{ICT}+0.630 \mathrm{LO}+0.351 \mathrm{AO}, \text { Errorvar }=0.232, \\
\text { R-square }=0.768
\end{gathered}
$$

\section{CONCLUSIONS AND RECOMMENDATIONS}

\section{A. Conclusion}

The research concluded that ICT significantly positive influence on ambidexterity. Meanwhile, ICT has not significantly positive influence on innovative performance. The research found learning organization significantly positive influence both on ambidexterity and innovative performance. It also can be concluded that Ambidexterity significantly positive influence on innovative performance. Regarding the mediating role of ambidexterity, this research found ICT significantly positive influence on innovative performance by mediating ambidexterity. But, related with the mediating role of ambidexterity in mediating learning organization on innovative performance, this research found that it has not significantly mediated the influence of learning organization on innovative performance. The summary of the research is 5 hypothesis are accepted $(\mathrm{H} 1, \mathrm{H} 3, \mathrm{H} 4, \mathrm{H} 5$ and $\mathrm{H} 6)$, meanwhile it rejected 2 hypothesis ( $\mathrm{H} 2$ and $\mathrm{H} 7$ ).

\section{B. Recommendation}

Based on research that has been done related to variables, we suggest some of the following:

1. The study was limited to respondents in millennial workforce in Jakarta, Banten, West Java and Riau provinces. Therefore, future studies should extend to wider range of respondent's age and domicile, so that the results obtained will be more accurate.

2. The management of the companies should consider policies that will be done in an effort to improve innovative performance, namely:

a. Improving the ICT capabilities of the employee by facilitate the software and hardware facilities and encourage the employee to optimize the use of online media available.

b. Improve learning organization by enhancing the knowledge management and competence of the employee.

c. Improving the ambidexterity ability of the employee in company to face the change process. Increased ambidexterity of leaders will have an impact on the ability to control the business processes in order to improve the company's performance.

\section{REFERENCES}

[1] Chao, Á. D., Gonzále, J. S., \& Sellens, J. T. (2015). ICT, innovation, and firm productivity: New evidence from small local firms. Journal of $\begin{array}{lll}\text { Business } & \text { Research, 68(7), 1439-1444. }\end{array}$ https://doi.org/10.1016/j.jbusres.2015.01.030.

[2] Jorgenson, D. W., \& Vu, K. (2007). Information technology and the world growth resurgence. German Economic Review. https://doi.org/10.1111/j.1468-0475.2007.00401.x.

[3] Jorgenson, D. W., Ho, M. S., \& Stiroh, K. J. (2008). A retrospective look at the U.S. productivity growth resurgence. In Journal of Economic Perspectives. https://doi.org/10.1257/jep.22.1.3.

[4] Ceccobelli, M., Gitto, S., \& Mancuso, P. (2012). ICT capital and labour productivity growth: A non-parametric analysis of 14 OECD countries. Telecommunications https://doi.org/10.1016/j.telpol.2011.12.012

[5] Jorgenson, D. W., Ho, M. S., \& Samuels, J. D. (2011). Information technology and U.S. productivity growth: Evidence from a prototype industry production account. Journal of Productivity Analysis. https://doi.org/10.1007/s11123-011-0229-z

[6] Gërguri-Rashiti, S., Ramadani, V., Abazi-Alili, H., Dana, L. P., \& Ratten, V. (2017). ICT, Innovation and Firm Performance: The 
Transition Economies Context. Thunderbird International Business Review. https://doi.org/10.1002/tie.21772.

[7] Guillemette, M. G., \& Paré, G. (2012). Toward a new theory of the contribution of the IT function in organizations. MIS Quarterly: Management Information Systems. https://doi.org/10.2307/41703466.

[8] Schertler, W., \& Berger-Koch, C. (1999). Tourism as an information business: The Strategic Consequences of e-Commerce for Business Travel. In Information and Communication Technologies in Tourism 1999. https://doi.org/10.1007/978-3-7091-6373-3_3.

[9] Maslach, D. (2016). Change and persistence with failed technological innovation. Strategic Management Journal, 37(4), 714-723. https://doi.org/10.1002/smj.2358.

[10] Carmeli, A., \& Dothan, A. (2017). Generative work relationships as a source of direct and indirect learning from experiences of failure: Implications for innovation agility and product innovation. Technological Forecasting and Social Change, 119, 27-38. https://doi.org/10.1016/j.techfore.2017.03.007.

[11] Argote, L. (2014). Knowledge Transfer and Organizational Learning. In The Wiley Blackwell Handbook of the Psychology of Training, Development, and Performance Improvement. https://doi.org/10.1002/9781118736982.ch9.

[12] Bresman, H. (2010). External learning activities and team performance: A multimethod field study. Organization Science. https://doi.org/10.1287/orsc.1080.0413.

[13] Xu, H., Zhang, X., Liu, L., \& Hong, J. (2017). Value effect of rival innovation failure: competition or contagion? China Journal of $\begin{array}{lrrr}\text { Accounting } & \text { Studies, } & \text { 5(4), }\end{array}$ https://doi.org/10.1080/21697213.2017.1423777.

[14] Felin, T., \& Zenger, T. R. (2014). Closed or open innovation? Problem solving and the governance choice. Research Policy. https://doi.org/10.1016/j.respol.2013.09.006.

[15] Natalicchio, A., Messeni Petruzzelli, A., \& Garavelli, A. C. (2017) Innovation problems and search for solutions in crowdsourcing platforms - A simulation approach. Technovation, 64-65(May), 28-42. https://doi.org/10.1016/j.technovation.2017.05.002.

[16] Ratten, V. (2016). Social media innovations and creativity. In Revolution of Innovation Management: The Digital Breakthrough Volume 1. https://doi.org/10.1057/978-1-137-57475-6_8.

[17] Wilkinson, T. J., \& Thomas, A. R. (2014). Innovation's second step. Thunderbird International Business Review. https://doi.org/10.1002/tie.21621.

[18] Gray, J. V., Roth, A. V., \& Leiblein, M. J. (2009). Quality risk in offshore manufacturing: An explanation and empirical test. In Academy of Management 2009 Annual Meeting: Green Management Matters, AOM 2009.

[19] Afuah, Allan, Tucci, C. (2012). Studying the Origins of Social Entrepreneurship: Compassion and Does Compassion Matter to Social Entrepreneurship. Academy of Management Review. https://doi.org/10.5465/amr.2012.0429.

[20] Sieg, J. H., Wallin, M. W., \& von Krogh, G. (2010). Managerial challenges in open innovation: A study of innovation intermediation in the chemical industry. $R$ and $D$ Management. https://doi.org/10.1111/j.1467-9310.2010.00596.x.

[21] Guzzini, E., Iacobucci, D., \& Palestrini, A. (2018). Collaboration for innovation and project failure. A dynamic analysis. Economics of

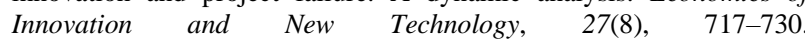
https://doi.org/10.1080/10438599.2017.1389125.

[22] Buesa, M., Heijs, J., \& Baumert, T. (2010). The determinants of regional innovation in Europe: A combined factorial and regression knowledge production function approach. Research Policy. https://doi.org/10.1016/j.respol.2010.02.016.

[23] Setiawan, K., \& Santoso, B. (2017). Influence of Managerial Leadership, Corporate Culture and Erp Implementation on Corporate Performance. Aktual'ni Problemy Ekonomiky = Actual Problems in $\begin{array}{llll}\text { Economics, (189), 253-259. } & \text { Retrieved from }\end{array}$ https://search.proquest.com/docview/1891693125? accountid=14701\%0 Ahttp://sfx.scholarsportal.info/ottawa?url_ver=Z39.88-

2004\&rft_val_fmt=info:ofi/fmt:kev:mtx:journal\&genre=article\&sid=P roQ:ProQ\%3Aabiglobal\&atitle=INFLUENCE+OF+MANAGERIAL+ LEADERSHIP\%2C+CORPORAT.

[24] Lungeanu, R., Stern, I., \& Zajac, E. J. (2016). When do firms change technology-sourcing vehicles? the role of poor innovative performance and financial slack. Strategic Management Journal. https://doi.org/10.1002/smj.2371.

[25] Ajayi, O. M. (2013). The impact of employee ambidexterity on organisational and marketing innovations: organisational context for exploiting the present and exploring for the future. Retrieved from http://sfx.scholarsportal.info/ottawa?url_ver=Z39.88-

2004\&rft_val_fmt=info:ofi/fmt:kev:mtx:dissertation\&genre=dissertatio ns+\%26+theses\&sid=ProQ:ProQuest+Dissertations+\%26+Theses+Glo
bal\&atitle=\&title=The+impact+of+employee+ambidexterity+on+organ isational+a.

[26] Curado, C., Muñoz-Pascual, L., \& Galende, J. (2018). Antecedents to innovation performance in SMEs: A mixed methods approach. Journal of Business Research, 89(June 2017), 206-215. https://doi.org/10.1016/j.jbusres.2017.12.056.

[27] Preda, A., Crisan, D., \& Stanica, J. (2014). The Impact of Ict On Innovation Performance in Europe. Case of Romania. Journal of Information Systems \& Operations Management, 8(1), 197-206. Retrieved http://www.rebe.rau.ro/RePEc/rau/jisomg/Su14/JISOM-SU14A16.pdf.

[28] Tajasom, A., Hung, D. K. M., Nikbin, D., \& Hyun, S. S. (2015). The role of transformational leadership in innovation performance of Malaysian SMEs. Asian Journal of Technology Innovation, 23(2), 172188. https://doi.org/10.1080/19761597.2015.1074513.

[29] Cruz-Cázares, C., Bayona-Sáez, C., \& García-Marco, T. (2013). You can't manage right what you can't measure well: Technological innovation efficiency. Research Policy, 42(6-7), 1239-1250. https://doi.org/10.1016/j.respol.2013.03.012.

[30] Abas \& Raja (2015), Impact of psychological capital on innovative performance and job stress, Canadian Jopurnal of Administrative Sciences, Volume 32, Issue 2, p. 128-138.

[31] Kilic, K., Ulusoy, G., \& Gunday, G. (2014). Journal of Engineering and Innovativeness, operations priorities and corporate performance: An analysis based on a taxonomy of innovativeness. Journal of Engineering and Technology Management, 1-19. https://doi.org/10.1016/j.jengtecman.2014.09.001.

[32] Higón, D. A. (2012). The impact of ICT on innovation activities: Evidence for UK SMEs. International Small Business Journal, 30(6), 684-699. https://doi.org/10.1177/0266242610374484.

[33] Bloom, N., Garicano, L., Sadun, R., \& Van Reenen, J. (2014). The Distinct Effects of Information Technology and Communication Technology on Firm Organization. Management Science, 60(12), 2859 2885. https://doi.org/10.1287/mnsc.2014.2013.

[34] Sadikin, M., Hardi, H., \& Haji, W. H. (2014). IT Governance Self Assessment in Higher Education Based on COBIT Case Study: University of Mercu Buana. Journal of Advanced Management Science, 2(1), 83-87. https://doi.org/10.12720/joams.2.2.83-87.

[35] Steoarthritis, K. N. E. E. O. (2008). O Utcomes of D Ifferent T Ypes of R Esistance T Raining on P Eople With, 2011, 1-13.

[36] Garcia-Alcaraz, J. L., Maldonado-Macias, A. A., Alor-Hernandez, G., \& Sanchez-Ramirez, C. (2017). The impact of information and communication technologies (ICT) on agility, operating, and economical performance of supply chain. Advances in Production $\begin{array}{llll}\text { Engineering } \& \text { Management, } & \text { 29-40. }\end{array}$ https://doi.org/10.14743/apem2017.1.237.

[37] Guinot, J., Chiva, R., \& Mallén, F. (2013). Organizational trust and performance: Is organizational learning capability a missing link? Journal of Management and Organization, 19(5), 559-582. https://doi.org/10.1017/jmo.2014.3.

[38] Cyert \& March, (1963), A Perspective from Organizational Economics, NBER Working group in Organizational Economics, SEPR.

[39] Argyris \& Scho“n, (1978), Organizational learning II: Theory method and practice Reading: Addison-Wesley, XXIX +305 pp, ISBN 0-20162983-6.

[40] Hedberg, (1981), How Organizations Learn and Unlearn', in P Nystrom \& WH Starbuck (eds.), Handbook of Organizational Design (Vol. 1), Cambridge University Press, London.

[41] Senge, (1990), The Fifth Discipline. The Art And Practice Of The Learning Organization. New York: Doubleday Currency.

[42] Brown \& Duguid, (1991), Organizational learning and communities-ofpractice: Toward a unified view of working, learning, and innovation. Organization Science, 2(1), 40-57.

[43] Dibella, Nevis, \& Gould, (1996), Understanding Organizational Learning Capability," Journal of Management Studies, Vol. 33, No. 3, 1996, pp. 361-379. doi:10.1111/j.1467-6486.1996.tb00806.x.

[44] Chiva, Alegre, and Lapiedra (2007), Measuring Organisational Learning Capability among the Workforce, International Jpurnal Manpower, No. 28(3/4):224-242DOI:10.1108/01437720710755227.

[45] Erkelens, R., van den Hooff, B., Huysman, M., \& Vlaar, P. (2015) Learning from Locally Embedded Knowledge: Facilitating Organizational Learning in Geographically Dispersed Settings. Global Strategy Journal, 5(2), 177-197. https://doi.org/10.1002/gsj.1092.

[46] Yan, M., Yu, Y., \& Dong, X. (2014). Organizational ambidexterity building via strategic learning and business learning. Proceedings of the Annual Hawaii International Conference on System Sciences, 3584 3593. https://doi.org/10.1109/HICSS.2014.446.

[47] Junni, P., Sarala, R. M., Taras, V. A. S., \& Tarba, S. Y. (2013). Organizational Ambidexterity and Performance: University of North 
Carolina at Greensboro University of North Carolina at Greensboro. The Academy of Management Perspectives, 27(4), 299-312.

[48] Lis, A., Józefowicz, B., Tomanek, M., \& Gulak-lipka, P. (2018). The Concept of the Ambidextrous Organization: Systematic Literature. International Journal of Contemporary Management, 17(1), 77-97. https://doi.org/10.4467/24498939IJCM.18.005.8384.

[49] Nosella, A., Cantarello, S., \& Filippini, R. (2012). The intellectual structure of organizational ambidexterity: A bibliographic investigation into the state of the art. Strategic Organization. https://doi.org/10.1177/1476127012457979.

[50] Goh \& Richards (1997), G. (1997). Benchmarking The Learning Capability of Organization, European Management Journal, Elsevier, vol. 15(5), pages 575-583, October..

[51] Duncan, R. B., \& Duncan, R. B. (1972). Characteristics of Organizational Environments and Perceived Environmental Uncertainty, 17(3), 313-327.

[52] Gibson, C. B. (2004). The Antecedents, Consequences, And Mediating Role of Organizational Ambidexterity, 47(2), 209-226.

[53] Cembrero, D. (2011). Ambidexterity as a Solution for the Challenge of Organizing Innovation David Ruiz de Olano Francisco González-Bree, (June).

[54] Turner, N., Maylor, H., \& Swart, J. (2015). Ambidexterity in projects: An intellectual capital perspective. International Journal of Project Management, 33(1), https://doi.org/10.1016/j.ijproman.2014.05.002.

[55] Fu, N., Flood, P. C., \& Morris, T. (2016). Organizational ambidexterity and professional firm performance: the moderating role of organizational capital. Journal of Professions and Organization, 3(1), 1-16. https://doi.org/10.1093/jpo/jov010.

[56] O'Reilly, C. A., \& Tushman, M. (2013). Organizational Ambidexterity: Past, Present and Future. SSRN. https://doi.org/10.2139/ssrn.2285704.

[57] Wang, Z., Huang, J., \& Tan, B. (2012). Managing Organizational Identity Through Ambidextrous Capabilities: A Dual Level Analysis. PACIS 2012 Proceedings.

[58] Cao, Q., Gedajlovic, E., \& Zhang, H. (2009). Unpacking Organizational Ambidexterity: Dimensions, Contingencies, and Synergistic Effects. Organization Science. https://doi.org/10.1287/orsc.1090.0426.

[59] Del Giudice, M., Soto-Acosta, P., Carayannis, E., \& Scuotto, V. (2018) Emerging perspectives on business process management (BPM): ITbased processes and ambidextrous organizations, theory and practice. Business Process Management Journal, 24(5), 1070-1076. https://doi.org/10.1108/BPMJ-09-2018-336.

[60] Chen, Y. Y., Yeh, S. P., \& Huang, H. L. (2012). Does knowledge management "fit" matter to business performance? Journal of Knowledge Management, 16(5), 671-687. https://doi.org/10.1108/13673271211262745.

[61] Sher, P. J., \& Lee, V. C. (2004). Information technology as a facilitator for enhancing dynamic capabilities through knowledge management. Information and Management. https://doi.org/10.1016/j.im.2003.06.004

[62] Relationships, I., Im, G., Rai, A., \& Im, G. (2014). IT-Enabled Coordination for Ambidextrous IT-Enabled Coordination for Ambidextrous Interorganizational Relationships, (April).

[63] Bresciani, S., Ferraris, A., \& Del Giudice, M. (2018). The management of organizational ambidexterity through alliances in a new context of analysis: Internet of Things (IoT) smart city projects. Technological Forecasting and Social Change, 136, 331-338. https://doi.org/10.1016/j.techfore.2017.03.002.

[64] Buchana, Y., Garbutt, M., \& Seymour, L. F. (2018). Identifying microlevel generative mechanisms of ICT-enabled performance improvement in resource-constrained healthcare organisations: A critical realist perspective. Electronic Journal of Information Systems in Developing Countries, 84(6), 1-11. https://doi.org/10.1002/isd2.12057.

[65] Kunz, W., Schmitt, B., \& Meyer, A. (2011). How does perceived firm innovativeness affect the consumer? Journal of Business Research. https://doi.org/10.1016/j.jbusres.2010.10.005.

[66] Cardona, M., Kretschmer, T., \& Strobel, T. (2013). ICT and productivity: Conclusions from the empirical literature. Information Economics and
https://doi.org/10.1016/j.infoecopol.2012.12.002.

[67] Algharibi, A. J., \& Arvanitis, T. N. (2011). Adapting the Unified Theory of Acceptance and Use of Technology (UTAUT) as a tool for validating user needs on the implementation of e-Trial software systems. In Proceedings of HCI 2011 - 25th BCS Conference on Human Computer Interaction. https://doi.org/10.14236/ewic/hci2011.1.

[68] Jacobsen, J., Fosse, H. B., \& Sorensen, A. (2018). ITT Intensive Machinery and Equipment, Organizational Change and Productivity Growth. SSRN Electronic Journal. https://doi.org/10.2139/ssrn.3096420.

[69] March, J. G. (1991). Exploration and Exploitation in Organizational
Learning. Organization Science. https://doi.org/10.1287/orsc.2.1.71.

[70] Amaral, G., Bushee, J., Cordani, U. G., KAWASHITA, K., Reynolds, J. H., ALMEIDA, F. F. M. D. E., ... Junho, M. do C. B. (2013) Ambidexterity, Organizational Factors and Environment on Organization's Performance. Journal of Petrology. https://doi.org/10.1017/CBO9781107415324.004.

[71] Park, Y. K., Song, J. H., Yoon, S. W., \& Kim, J. (2014). Learning organization and innovative behavior: The mediating effect of work engagement. European Journal of Training and Development, 38(1-2), 75-94. https://doi.org/10.1108/EJTD-04-2013-0040.

[72] Škerlavaj, M., Song, J. H., \& Lee, Y. (2010). Organizational learning culture, innovative culture and innovations in South Korean firms. Expert Systems with Applications, 37(9), 6390-6403. https://doi.org/10.1016/j.eswa.2010.02.080.

[73] Siagian, G. S., \& Ikatrinasari, Z. F. (2019). Pengaruh Manajemen Pengetahuan Terhadap Inovasi: Kasus Industri IT di Indonesia. Operations Excellence: Journal of Applied Industrial Engineering, 11(1), 71. https://doi.org/10.22441/oe.v10.3.2018.017.

[74] Valaei, N., Rezaei, S., \& Ismail, W. K. W. (2017). Examining learning strategies, creativity, and innovation at SMEs using fuzzy set Qualitative Comparative Analysis and PLS path modeling. Journal of Business Research. https://doi.org/10.1016/j.jbusres.2016.08.016.

[75] Morales, V. J. G., Barrionuevo, M. J., \& Montes, F. J. L. (2011). Influence of the level of learning in the organizational innovation and performance: Driving factors of learning. Revista Europea de Direccion y Economia de La Empresa.

[76] Jiménez-Jiménez, D., \& Sanz-Valle, R. (2011). Innovation, organizational learning, and performance. Journal of Business Research, 64(4), 408-417. https://doi.org/10.1016/j.jbusres.2010.09.010.

[77] Simsek, Z., Heavey, C., Veiga, J. F., \& Souder, D. (2009). A typology for aligning organizational ambidexterity's conceptualizations, antecedents, and outcomes. Journal of Management Studies. https://doi.org/10.1111/j.1467-6486.2009.00841.x.

[78] Wang, C. L., \& Rafiq, M. (2012). Ambidextrous Organizational Culture, Contextual Ambidexterity and New Product Innovation: A Comparative Study of UK and Chinese High-tech Firms. https://doi.org/10.1111/j.1467-8551.2012.00832.x.

[79] Simsek, Z. (2009). Organizational ambidexterity: Towards a multilevel understanding. Journal of Management Studies. https://doi.org/10.1111/j.1467-6486.2009.00828.x.

[80] Sarkees, M., Hulland, J., \& Prescott, J. (2010). Ambidextrous organizations and firm performance: The role of marketing function implementation. Journal of Strategic Marketing, 18(2), 165-184. https://doi.org/10.1080/09652540903536982.

[81] Popadić, M., Černe, M., \& Černe, M. (2016). Exploratory and exploitative innovation: The moderating role of partner geographic diversity. Economic Research-Ekonomska Istrazivanja, 29(1), 11651181. https://doi.org/10.1080/1331677X.2016.1211951.

[82] Kosasih, K., Wibowo, \& Saparuddin. (2020). The influence of ambidextrous organization and authentic followership on innovative performance: The mediating role of change readiness. Management Science Letters, 10(7), 1513-1520. https://doi.org/10.5267/j.msl.2019.12.015.

[83] Faisal Ahammad, M., Mook Lee, S., Malul, M., \& Shoham, A. (2015). Behavioral Ambidexterity: The Impact of Incentive Schemes on Productivity, Motivation, and Performance of Employees in Commercial Banks. Human Resource Management. https://doi.org/10.1002/hrm.21668. 